УДК 316.62:394

DOI https://doi.org/10.32782/humanitas/2021.6.6

\title{
Яна МАРТИНЮК
}

аспірантка, Київський університет імені Бориса Грінченка, бульвар I. Шамо, 18/2, м. Київ, Україна, 02154

ORCID: 0000-0003-2646-5845

Бібліографічний опис статті: Мартинюк, Я. (2021) Організація волонтерської діяльності в умовах територіальної громади. Ввічливість. Humanitas, 6, 38-43, doi: https://doi.org/10.32782/humanitas/2021.6.6

\section{ОРГАНІЗАЦІЯ ВОЛОНТЕРСЬКОЇ ДІЯЛЬНОСТІ В УМОВАХ ТЕРИТОРІАЛЬНОЇ ГРОМАДИ}

\begin{abstract}
В Україні динамічно розвивається державна політика з питань децентралізації влади та створення територіальних громад, що передбачає передачу повноважень із державного рівня до органів місчевого самоврядування громади. Все більше прав, компетенцій, можливостей, коштів переходить у розпорядження територіальної громади та ї̈ мешканців. Одним із важливих інструментів змін є волонтерська діяльність та активізація мешканців щодо покращення життя у громаді свойми силами. Залучення мешканців до визначення нагальних проблем спільноти, зацікавленість жителів у пошуку шляхів їх вирішення спонукає до рішучих дій щодо впровадження визначених кроків із вирішення проблем громади. Від соиіальної активності та згуртованості мешканців залежить те, наскільки швидко відбудуться зміни в їх громаді, які сфери життя буде охоплено та за якими напрямами буде налагоджена волонтерська робота. Якщо грамотно підійти до організації волонтерської діяльності в територіальній громаді, залучивщи мешканиів до роботи та створивши ініціативні волонтерські групи, можна вирішити проблеми громади, тим самим покращчтти життя ії мешканців, підняти громаду на новий рівень. Однією з інновачійних форм роботи із громадою є онлайн-волонтерство, щчо полегшує організацію волонтерської діяльності у громаді. Мета статті полягає в розгляді основних ознак територіальної громади та аспектів волонтерської діяльності, які впливають на розвиток та організацію волонтерства у територіальній громаді. Гостро постає питання відсутності сталих алгоритмів та етапів організації волонтерської діяльності в територіальній громаді щодо вирішення соиіальних проблем ї̈ мешканиів.

Автором досліджено сутність територіальної громади як об'єкта волонтерської діяльності; розкрито уявлення про організацію волонтерської діяльності в територіальних громадах, особливості роботи волонтерів в умовах сьогодення; обтрунтовано основні поняття: «територіальна громада» та «волонтерська діяльність y територіальній громаді». Також автором виокремлено основні ознаки територіальної громади та схарактеризовано специфіку організащії волонтерської діяльності в територіальній громаді.

Ключові слова: громада, територіальна громада, волонтерська діяльність, волонтерська діяльність у територіальній громадi.
\end{abstract}

\section{Yana MARTYNIUK}

Postgraduate Student, Borys Grinchenko Kyiv University, 18/2 I. Shamo Boulevard, Kyiv, Ukraine, 02154 ORCID: 0000-0003-2646-5845

To cite this article: Martyniuk, Ya. (2021). Orhanizatsiia volonterskoi diialnosti v umovakh terytorialnoi hromady [Organizing volunteer activity in a territorial community]. Vvichlyvist. Humanitas, 6, 38-43, doi: https://doi.org/10.32782/humanitas/2021.6.6

\section{ORGANIZATION OF VOLUNTEER ACTIVITIES IN A TERRITORIAL COMMUNITY}

At the present time in Ukraine, the state policy on the decentralization of power and establishment of territorial communities is dynamically developing which involves the transfer of powers from the state level to local self-government bodies of the community. More and more rights, powers, opportunities, and resources are transferred to the control of the territorial community and its residents. One of the important tools of change is volunteer activities and activation of residents to improve life in the community by their own efforts. Involving residents in identifying general community problems, involving them in finding ways to solve them, thereby encouraging the community to take decisive actions to implement the identified criteria for solving community problems and, as a result, making the community active and active. The social activity and involvement of residents determine how quickly changes will take place in their community, which spheres of life will be supported, and in which areas the work will be created. If you can competently approach 
the organization of volunteer activities in a territorial community by involving the residents in the work and creating initiative volunteer groups, you can solve the problems of the community, thereby improving the lives of its residents and raising the community to a new level. One of the innovative forms of working with the community is online volunteering, which facilitates the organization of volunteer activities in the community. The goal of this article is to look at the main features of the territorial community and the aspects of volunteer activities that affect the development and organization of volunteering in the territorial community. Thus, the lack of steel algorithms and stages of organization of volunteering activities in the territorial community, in order to solve social problems of its residents is an urgent issue.

This article examines the essence of the territorial community as a subject of volunteer activities and its residents as a subject of these activities; it reveals the concept of organization of volunteer activities in territorial communities, the peculiarities of volunteers' work in the present conditions.

The essence of the basic understanding of "territorial community" and "volunteer activities in the territorial community" is revealed. The main features of a territorial community are specified. The specifics of the organization of volunteering activities in the territorial community are characterized.

Key words: community, territorial community, volunteer activities, volunteer activities in the territorial community.

Постановка проблеми. Розвиток децентралізації в Україні передбачає перехід влади та іiі механізмів керування до громади, саме тому мешканці виступають рушійною силою у вирішенні місцевих, територіальних проблем, ïx вивченні та пошуку шляхів їх вирішення. Територіальна громада $\epsilon$ основним первинним суб'єктом організації волонтерської діяльності для вирішення соціальних проблем громади.

Нині надзвичайно актуальним є застосування різних технологій для організації волонтерської діяльності щодо вирішення нагальних проблем у територіальній громаді. Особливістю є співпраця влади територіальної громади та iï мешканців у спільному прийнятті рішень на місцевому рівні задля покращення умов розвитку громади. Проблема повноцінної організації волонтерської діяльності у територіальній громаді полягає у відсутності конкретних технологій та алгоритмів їх упровадження.

Аналіз досліджень. Проблеми громади досліджували такі вітчизняні науковці, як: В. Звонар, Т. Сила, I. Козубовська, М. Бриль, О. Врублевський, О. Данчева, Е. Чубаров, Т. Репицький, Ю. Ткачук, Б. Шевчук; питання роботи в громаді розробляли О. Безпалько, Г. Слозанська, Т. Семигіна, В. Сидорова; технологіями залучення громади до волонтерської діяльності переймалися В. Петрович, О. Кузьменко, Н. Романова, Ю. Поліщук, Т. Лях, 3. Бондаренко.

Мета статті. Незважаючи на значну кількість наукових праць щодо різних аспектів волонтерської діяльності, питання організації волонтерської діяльності в умовах територіальної громади потребує подальшого грунтовного вивчення.

Виклад основного матеріалу. Сьогодні розвиваються інноваційні підходи до заохочення громадян до участі в місцевому самовряду- ванні, підтримки та поширення волонтерських ініціатив членів громади.

Як зазначає I. Козубовська у роботі «Територіальна громада як об'єкт діяльності фахівця із соціальної роботи», громада - це об'єднання людей, які мешкають на одній географічній місцевості, мають спільні проблеми, інтереси, соціальні характеристики або зв'язки (Козубовська, 2019). Автор окреслює територіальну громаду як територіальну спільноту, що складається з фізичних осіб, які постійно мешкають, працюють на спільній території, безпосередньо або через сформовані ними муніципальні структури вирішують питання місцевого значення, мають спільну комунальну власність, володіють на цій території нерухомим майном, сплачують комунальні податки та пов'язані територіально-особистісними зв'язками системного характеру (Козубовська, 2019).

Кандидат соціологічних наук В. Саакян зазначає, що громада - це групова соціальна спільнота, члени якої поділяють єдину територію та об'єднані повсякденними регулярними стосунками, відрізняється від інших спільнот індивідуальністю та емоційністю внутрішніх зв'язків, що зумовлюється родовими, сусідськими i товариськими взаємостосунками, культурою, замкнутістю системи (Саакян, 2002). Автор стверджує, що членів громади об'єднує спільне територіальне проживання, колективні зв'язки та стосунки.

У Законі України «Про місцеве самоврядування в Україні» територіальна громада - це жителі, об'єднані постійним проживанням у межах села, селища, міста, що є самостійними адміністративно-територіальними одиницями, або добровільне об'єднання жителів кількох сіл, селищ, міст, що мають єдиний адміністративний центр (Про місцеве самоврядування в Україні, 2021). 
В Указі Президента України «Про заходи щодо впровадження Концепції адміністративної реформи в Україні» трактується поняття «територіальна громада» як спільнота мешканців, жителів населених пунктів (сіл, селищ, міст), об'єднаних загальними інтересами у вирішенні питань місцевого значення як безпосередньо, так і через органи місцевого самоврядування (Указ, 2006). Тож визначення територіальної громади в законах України робить наголос на спільній території проживання та спільному органі самоврядування.

Б. Шевчук говорить, що громада - це мешканці, які спільно проживають на певній території, мають визначений законодавством правовий статус, ідентифікують себе із нею і мають спільні інтереси (Шевчук, 2019). Науковець акцентує увагу на жителях, які ототожнюють себе зі спільнотою та поділяють спільні інтереси громади, в якій проживають.

Проаналізувавши різні думки щодо визначення громади, можна виділити такі спільні ознаки територіальної громади, як: спільна територія проживання в межах певних кордонів; спільні інтереси громади; соціальна взаємодія мешканців; ідентифікація мешканців громади зі спільнотою; встановлений законодавчо правовий статус; спільна комунальна власність.

Також громада як різновид соціального середовища має низку функцій, спрямованих на визначення спільних цінностей, традицій, норм, санкцій, моделей та норм поведінки жителів громади: ціннісно-орієнтовану; культурологічну; нормативно-правову; соціального контролю; інтегративну (Безпалько, 2006)

Т. Лях у праці «Методика організації волонтерських груп» наголошує, що волонтерська діяльність - це спосіб підтримки, піклування, надання допомоги членам громади; взаємодії між людьми для спільного вироблення нових шляхів вирішення проблем, які виникають (Лях, 2010). Головною думкою є надання допомоги громадянам у співпраці «людина - людині» та вирішення суспільних проблем.

У Законі України «Про волонтерську діяльність» зазначено, що волонтерська діяльність добровільна, безкорислива, соціально спрямована, неприбуткова діяльність, що здійснюється волонтерами та волонтерськими організаціями шляхом надання волонтерської допомоги (Про волонтерську діяльність, 2020). Підкреслю- ється саме безкорислива, соціально спрямована допомога, яка може надаватися як конкретним громадянином, так і організаціями.

Волонтерська діяльність у територіальній громаді буде ефективною лише у разі залучення громадою організацій та волонтерів, які мають досвід у налагодженні волонтерської діяльності, або ж людей, котрі готові надати знання та поділитися досвідом ефективного впровадження волонтерських проєктів у територіальних громадах, знайти шляхи до зацікавлення, включення та активізації мешканців до волонтерської діяльності. Можна виокремити два шляхи розвитку подальших дій.

Перший - залучені волонтери надають знання, розвивають навички, розглядають шляхи створення волонтерського руху в громаді спільно з мешканцями. Надання методів, технологій та принципів налагодження волонтерства у територіальній громаді, де громада зацікавлена в отримані знань. Другий - надання безпосередньої допомоги тим мешканцям, які іiі потребують (матеріальної, речової, юридичної тощо), де мешканці громади виступають пасивними отримувачами послуг.

Отже, можна виділити три характерні особливості волонтерської діяльності: діяльність має бути неприбутковою; діяльність повинна бути добровільною, згідно 3 особистою волею індивідуума; діяльність повинна бути корисною кому-небудь, не тільки волонтеру, або суспільству загалом.

Волонтерська діяльність у територіальній громаді - це добровільна, безкоштовна допомога, яка спрямована на вирішення соціальних проблем шляхом активізації мешканців громади і залучення їх до волонтерської діяльності, котра мотивує та згуртовує мешканців до вирішення спільних проблем і питань, об'єднує лідерів до спільної роботи на благо суспільства, організовує волонтерську роботу в громаді.

Для того, щоб ефективно організувати роботу в громаді, потрібно чітко розуміти та розмежовувати їх види, адже для кожної з них притаманні ті чи інші особливості, які потрібно враховувати. В Україні у системі місцевого самоврядування варто виокремлювати такі види територіальної громади: територіальні громади базового рівня (сільські, селищні, міські); територіальні громади факультативного рівня (районів, областей). При цьому у межах тери- 
торіальних громад факультативного рівня реалізуються колективні територіальні інтереси територіальних громад сіл, селищ і міст. Натомість сільські, селищні, міські територіальні громади є спільнотами, у межах яких здійснюється життєдіяльність населення, жителів певних адміністративно-територіальних одиниць (Про волонтерську діяльність, 2021).

Для організації роботи волонтерів у територіальній громаді потрібно орієнтуватися в їх типології, розуміти, яка група волонтерів і чим може займатися в територіальній місцевості, на що та чи інша група може спрямувати свої сили, в якому напрямі вона компетентна, на який час може бути організована ця група тощо. Всі ці фактори впливають на продуктивність роботи та на їі результат.

Так, Т. Лях класифікує волонтерів за такими ознаками, як: вік; ступінь професіоналізму; тривалість волонтерської діяльності; соціальна роль/ статус; ступінь мобільності; досвід волонтерської роботи; приналежність до організації; склад волонтерської групи (Лях, 2009). Отже, волонтером може бути будь-хто, незважаючи на вік, стать, соціальний статус чи ступінь професіоналізму, що розширює можливість впливу на громаду.

Коли в громаді вже сформована ініціативна група волонтерів, їх можна поділити за певними ролями, які вони відіграють в організації, та їхньою участю в роботі організації на різних рівнях: напрям програм та політики; розроблення, планування та менеджмент; безпосереднє надання послуг; забезпечення підтримки матеріалами та обладнанням. Також такі громади можуть бути залучені до різноманітних програм, наприклад економічного, соціального розвитку, місцевих громад та господарства.

Волонтерська діяльність, котра планується та реалізується в територіальній громаді, повинна дотримуватися певних етапів, завдань, принципів роботи. Т. Семигіна виділяе такі завдання, як: налагодження та підтримка контактів 3 індивідами, групами й організаціями; розвиток профілю громади, оцінка іiі ресурсів i потреб; розроблення стратегічного аналізу і планування цілей, завдань і пріоритетів; співробітництво і ведення переговорів 3 іншими установами, закладами та фахівцями; ефективне втручання у розроблення і проведення політики, у тому числі налагодження контактів із місцевими політиками; робота 3 конкрет- ними людьми, включаючи консультування; керування ресурсами, включаючи штатний розпис та бюджет; підтримка груп та організацій в отриманні ресурсів, наприклад через заявки на грант; контроль та оцінка прогресу, а також найефективнішого використання ресурсів; розроблення, контроль та оцінка стратегій рівних можливостей (Семигіна, 2002).

Для ефективної організації волонтерської діяльності в умовах громади потрібно розуміти та знати не лише завдання, а й напрями роботи в громаді (Закон, 2020):

- здійснення волонтерської допомоги 3 метою підтримки малозабезпечених, безробітних, багатодітних, бездомних, безпритульних, осіб, що потребують соціальної реабілітації;

- догляд за хворими, інвалідами, одинокими, людьми похилого віку та іншими особами, які через свої фізичні, матеріальні чи інші особливості потребують підтримки та допомоги;

- підтримка громадян, які постраждали внаслідок стихійного лиха, екологічних, техногенних та інших катастроф, у результаті соціальних конфліктів, нещасних випадків, а також жертв злочинів, біженців;

- здійснення волонтерської допомоги особам, які через свої фізичні або інші вади обмежені в реалізації своїх прав і законних інтересів;

- організація та проведення заходів, пов'язаних 3 охороною навколишнього природного середовища, збереженням культурної спадщини, історико-культурного середовища, пам'яток історії та культури, місць поховання;

- організація та проведення заходів національного та міжнародного значення, пов'язаних 3 організацією масових спортивних, культурних та інших видовищних і громадських заходів;

- ліквідація наслідків надзвичайних ситуацій техногенного або природного характеру (Про волонтерську діяльність, 2020).

Одним із головних елементів для визначення проблем та потреб конкретно тієї чи іншої громади є iї спроможність.

Великий тлумачний словник сучасної української мови трактує поняття спроможності як наявність умов, сприятливих для чого-небудь, обставин, які допомагають чомусь, можливість (Шевчук, 2019). Виділяються такі акценти у визначенні спроможності, як здатність до 
використання наявних умов, обставин для здійснення певної діяльності.

Спроможність територіальної громади визначає наявність умов (фінансових, інфраструктурних, кадрових), на основі яких у процесі функціонування визначається здатність територіальної громади надавати публічні послуги, а також можливість задіяти невикористаний та прихований потенціал (інвестиційний, економічний, людський, управлінський, фінансовий, громадської участі) задля розвитку територіальної громади.

Більшість територіальних громад, котрі мають повноваження самостійно вирішувати місцеві питання, стикаються з неспроможністю їх виконувати через через брак матеріальних та фінансових ресурсів; через низьку якість або відсутність інфраструктури; через брак кадрів відповідної кваліфікації; через пасивність мешканців щодо вирішення проблем громади.

Громада за своєю специфікою має різні сфери діяльності, які потрібно вдосконалювати, та напрями волонтерської роботи, які потрібно розвивати, а саме: приміські громади тяжіють до міст, відпочинкові - до розвитку туризму, прикордонні - до боротьби з виїздом громадян за кордон, громади, прилеглі до операції об'єднаних сил, до співпраці з військовими. Водночас практично в усіх громадах є однакові проблеми: вода, каналізація, звалище, дорога, соціальна інфраструктура та вкрай незадовільний менеджмент земельних ресурсів. Десь додаються демографічні, транспортні чи навіть правові проблеми.

Типовими напрямами волонтерської діяльності в територіальних громадах виділяють: благоустрій i озеленення; санітарна очистка й утилізація твердих побутових відходів; розвиток комунальної інфраструктури та комунальних інженерних мереж; підвищення якості та створення конкурентного ринкового середовища; надання комунальних послуг; вдосконалення руху громадського транспорту; ремонт доріг i територій; вирішення екологічних проблем, облаштування дитячих майданчиків, місць відпочинку і скверів; створення клубів за інтересами; поліпшення громадського правопорядку та вирішення проблем дитячої бездоглядності тощо.
Це підтверджує той факт що мешканці територіальної громади спрямовують свою увагу на ті проблеми, з якими жителі стикаються щодня, для місцевих вони $є$ пріоритетними.

Волонтери, потрібно зауважити, виконують безпосередню роботу з людьми, завжди перебуваючи в контакті із громадою, тому вони є важливим суб' єктом соціально-педагогічної діяльності, безпосередніми суб'єктами соціальної роботи, які працюють за різними напрямами в територіальній громаді.

Наше сьогодення вносить свої зміни в розвиток та організацію волонтерської діяльності в громадах, і події з пандемією у світі відобразилися також на волонтерстві. Пандемія COVID-19 внесла свої корективи у волонтерську діяльність, в напрями іiі роботи, карантинні заходи ускладнили повноцінну роботу волонтерських організацій та волонтерства загалом. Виникає новий формат волонтерської діяльності, такий як віртуальне волонтерство це інноваційний формат здійснення волонтерської діяльності через засоби масової інформації, а саме Інтернет, телефон, онлайн-формат волонтерських програм (Байдарова, 2021).

Перехід волонтерства в онлайн-формат має свої переваги (дотримання карантинних норм задля безпеки мешканців громади та волонтерів; започатковано нові форми роботи, наприклад доставка продуктів харчування та продуктів першої необхідності тим людям, які знаходяться на самоізоляції; підтримка громадян у телефонному режимі) та недоліки (відсутня комунікація волонтерів і мешканців громади через відсутність Інтернету; перенесення офлайн-формату зустрічей та проєктів на невизначений термін; труднощі у мотивації та залученні громадян до волонтерської діяльності; непідготовленість до роботи в онлайнформаті; відсутність платформи для неформального спілкування волонтерів) для роботи в громаді (Байдарова, 2021).

Отже, сучасні події впливають на розвиток волонтерської діяльності та стимулюють їі до розвитку та вдосконалення, пошуку нових форм та напрямів діяльності, методів та нових платформ роботи із громадою.

\section{ЛІТЕРАТУРА:}

1. Байдарова О., Дюльгерова А. Волонтерська діяльність в україні в умовах пандемії COVID-19. Social Work and Education. 2021. № 3. C. 311-328. 
2. Безпалько О.В. Організація соціально-педагогічної роботи з дітьми та молоддю у територіальній громаді: теоретико-методичні основи: Монографія. Київ : Науковий світ, 2006. 363 с.

3. «Про волонтерську діяльність» : Закон України від 19.04.2011 р. № 43 : станом на 3 лип. 2020 р. URL: https://zakon.rada.gov.ua/laws/show/3236-17\#Text

4. «Про місцеве самоврядування в Україні» : Закон України від 21.05.1997 p. № 24 : станом на 24 листоп. 2021 p. URL: https://zakon.rada.gov.ua/laws/show/280/97-вр\#Text

5. Козубовська I. Територіальна громада як об'єкт діяльності фахівця з соціальної роботи. Social Work and Education. 2019. № 6. C. 19-31.

6. Лях Т.Л. Соціально-педагогічна діяльність студентських волонтерських груп : дис. ... канд. пед. наук : 13.00.05. Луганськ, 2009. 301 с.

7. Лях Т.Л. Методика організації волонтерських груп. Київ : Київ. ун-т ім. Бориса Грінченка, 2010. 160 с.

8. Лях Т.Л., Фролова Л. Особливості організації діяльності волонтерських груп в умовах пандемії COVID-19. Актуальні проблеми соиіальної роботи та соиіального забезпечення : європейський та наиіональний вимір : Матеріали I Міжнар. науково-практ. конф., м. Луцьк, 27 трав. 2021 р. Луцьк, 2021. С. 208.

9. Саакян В.Э. Проявление и тенденции развития общины и общинности в Армении: автореф. автореферат диссертации на соискание ученой степени кандидат социологических наук : спец. 22.00.03. Ереван, 2002. 22 с.

10. Семигіна Т.В. Підготовка соціальних працівників до роботи в громаді. Наукові засади. 2002. Т. 20. C. 389-393. URL: http://ekmair.ukma.edu.ua/bitstream/handle/123456789/8662/Semygina_Pidgotovka_socialnyx_ pracivnykiv.pdf? sequence $=1 \&$ amp;isAllowed $=\mathrm{y}$

11. «Про заходи щодо впровадження Концепції адміністративної реформи в Україні» : Указ Презедента України від 22.07 .1998 р. : станом на 28 трав. 2006 p. URL: https://zakon.rada.gov.ua/laws/show/810/98\#Text

12. Шевчук Б.М. Територіальна громада: поняття, статус та ознаки. Ефективність державного управління. 2019. № 4. C. 39-49.

\section{REFERENCES:}

1. Baidarova O. (2021). Volonterska diyalnist v ukrayini v umovah pandemiyi COVID-19 [Volunteerism in Ukraine under conditions of pandemic COVID-19]. Social Work and Education - Social Work and Education, 3, 311-328 [in Ukrainian].

2. Bezpalko O.V. (2006). Organizaciya socialno-pedagogichnoyi roboti z ditmi ta moloddyu u teritorialnij gromadi: teoretiko-metodichni osnovi [The organization of socio-pedagogical work with children and young people in the territorial community: theoretical and methodological bases]. Kyiv [in Ukrainian].

3. Zakon Ukrayini «Pro volontersku diyalnist» [Law of Ukraine «On Volunteer Activity»]. ( 2020, July 03). zakon.rada.gov.ua. Retrieved from https://zakon.rada.gov.ua/laws/show/3236-17\#Text [in Ukrainian].

4. Zakon Ukrayini «Pro misceve samovryaduvannya v Ukrayini» [Law of Ukraine «On Local Self-Government in Ukraine»]. ( 2021, November, 24). zakon.rada.gov.ua. Retrieved from https://zakon.rada.gov.ua/laws/show/280/97$\% \mathrm{D} 0 \% \mathrm{~B} 2 \% \mathrm{D} 1 \% 80 \#$ Text [in Ukrainian].

5. Kozubovska I. (2019). Teritorialna gromada yak bo'yekt diyalnosti fahivcya z socialnoyi robogti [Territorial community as a subject of activity of a social work practitioner]. Social Work and Education - Social Work and Education, 6, 25 [in Ukrainian].

6. Lyakh T.L. (2009). Cocialno-pedagogichna diyalnist studentskih volonterskih grup [Socio-pedagogical activities of volunteer groups: candidate of pedagogical sciences]. Candidate's thesis. Lugansk [in Ukrainian].

7. Lyakh T.L. Metodika organizaciyi volonterskih grup (2010). [Methods of organizing volunteer groups: tutorial]. Kyiv: Kiyivsk. un-t imeni Borisa Grinchenka - State University named after Boris Grinchenko [in Ukrainian].

8. Lyakh T.L. \& Frolova. L. (2021). Osoblivosti organizaciyi diyalnosti volonterskih grup v umovah pandemiyi COVID-19 [Peculiarities of organizing the activities of volunteer groups in the conditions of pandemic COVID-19]. FOP Ivanyuk V. P. - FOP Ivanyuk V. П., 208 [in Ukrainian].

9. Sahakyan V.E. (2002). Proyavlenie i tendencii razvitiya obshiny i obshinnosti v Armenii [Manifestation and trends of development of community and communality in Armenia]. Extended abstract of Doctor's thesis. Yerevan [in Armenia].

10. Semigina T.V. (2002). Pidgotovka socialnih pracivnikiv do roboti v gromadi [Preparation of social workers to work in the community]. (n.d.). ekmair.ukma.edu.ua. Retrieved from http://ekmair.ukma.edu.ua/bitstream/ handle/123456789/8662/Semygina_Pidgotovka_socialnyx_pracivnykiv.pdf?sequence=1 [in Ukrainian].

11. Bezpalko O.V.,Zviereva I.D., Veretenko T.G. (2013). Socialna pedagogika [Social pedagogy]. Kyiv : Academvydav [in Ukrainian].

12. Ukaz Prezedenta Ukrayini «Pro zahodi shodo vprovadzhennya Koncepciyi administrativnoyi reformi v Ukrayini» [Decree of the President of Ukraine «About the measures for the implementation of the Concept of administrative reform in Ukraine»]. (2006, May 28). zakon.rada.gov.ua. Retrieved from https://zakon.rada.gov.ua/laws/show/810/98\#Text

13. Shevchuk B.M. (2019). Teritorialna gromada: ponyattya, status ta oznaki [Territorial community: notion, status and signs]. Efektivnist derzhavnogo upravlinnya - Bogdan Mikhailovich Shevchuk, 4, 39-49 [in Ukrainian]. 